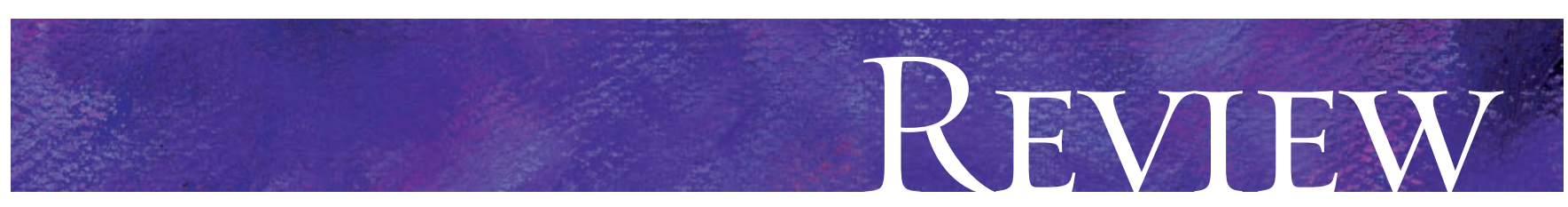

\title{
Sperm DNA damage: clinical significance in the era of assisted reproduction
}

\author{
Armand Zini, Jamie Libman
}

\section{ABSTRACT}

Evidence suggests that damage to human sperm DNA might adversely affect reproductive outcomes and that the spermatozoa of infertile men possess substantially more sperm DNA damage than do the spermatozoa of fertile men. This is particularly relevant in an era where advanced forms of assisted reproductive technologies are commonly used (technologies that often bypass the barriers to natural selection), because there is some uncertainty regarding the safety of using DNAdamaged spermatozoa. In this review, we outline our current understanding of how sperm DNA is organized, what causes sperm DNA damage, what impact this damage may have on reproductive capacity and whether tests of sperm DNA damage are clinically useful.

CMAJ 2006;175(5):495-500

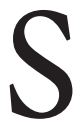
emen analysis is the cornerstone of the evaluation of infertile men. Semen volume and $\mathrm{pH}$ level are an index of seminal vesicle and prostate function. Sperm concentration, motility and morphology are largely determined by testicular function and, to a lesser extent, by post-testicular (e.g., epididymal) genital tract function. Although fertile men as a group have higher mean sperm parameters (concentration, motility and morphology) than do infertile men, there is significant overlap between these groups. ${ }^{1}$ Moreover, these factors are generally modest predictors of reproductive outcomes.

New markers are needed that might better discriminate infertile from fertile men and that may predict pregnancy outcome and the risk of adverse reproductive events. Conventional semen parameters fall short. There is now some evidence to suggest that markers of sperm DNA integrity may be better measures of male fertility potential than conventional measures, but larger studies are needed to define the clinical value of testing sperm DNA integrity. ${ }^{1-4}$ The study of sperm DNA damage is particularly relevant in an era where advanced forms of assisted reproductive technologies are frequently used.

Fertilization involves the direct interaction of the sperm $\infty$ and oocyte, fusion of the cell membranes and union of male and female gamete genomes. ${ }^{5}$ The completion of this process and subsequent embryo development depend in part on the inherent integrity of the sperm DNA. ${ }^{6}$ Indeed, there appears to be a threshold of sperm DNA damage (i.e., DNA fragmentation, abnormal chromatin packaging, protamine deficiency) beyond which embryo development and pregnancy are impaired. ${ }^{6,7}$ There is now clinical evidence to show that damage to human sperm DNA may adversely affect reproductive outcomes and that spermatozoa of infertile men possess substantially more DNA damage than do spermatozoa of fertile men. ${ }^{1-3,8}$ However, our understanding of the causes of sperm DNA damage and the full impact of this sperm defect on reproductive outcomes remains rudimentary.

In this review, we will outline our current understanding of how sperm DNA is organized, what causes sperm DNA damage, what impact this damage may have on reproductive capacity and whether tests of sperm DNA damage are clinically useful.

\section{Human sperm DNA and chromatin structure}

Unlike the relatively loose structure of chromatin (DNA and nuclear proteins) in somatic cells, sperm chromatin is tightly compacted because of the unique associations between the DNA and sperm nuclear proteins (predominantly highly basic proteins known as protamines; see Fig. I). ${ }^{9,10}$ During the later stages of spermatogenesis, the spermatid nucleus is remodelled and condensed, which is associated with the displacement of histones by transition proteins and then by protamines. ${ }^{11}$ The DNA strands are tightly wrapped around the protamine molecules (about $50 \mathrm{~kb}$ of DNA per protamine), forming tight and highly organized loops. ${ }^{10}$ Inter- and intramolecular disulfide cross-links between the cysteine-rich protamines are responsible for the compaction and stabilization of the sperm nucleus. It is thought that this nuclear compaction is important to protect the sperm genome from external stresses such as oxidation or temperature elevation. ${ }^{12}$

The current understanding is that sperm chromatin is tightly packaged by protamines, but up to $15 \%$ of the DNA remains packaged by histones at specific DNA sequences (i.e., there is a nonrandom association between histones and DNA sequences). ${ }^{13}$ The histone-bound DNA sequences are less tightly compacted, and it is thought that these DNA sequences or genes may be involved in fertilization and early embryo development. ${ }^{13}$ The retained histones are associated with the nuclear periphery and with telomeres (Fig. I). ${ }^{14}$ Infertile men, as compared with fertile controls, have an increased sperm histone : protamine ratio. ${ }^{11,15}$ An excess of nuclear histones (> $15 \%$ ) results in poorer chromatin compaction and a subsequent increased susceptibility to external stresses (e.g., oxidation or temperature elevation in the female reproductive tract). ${ }^{12}$ 
Although the bulk of the sperm DNA is in the nucleus, a small fraction is of mitochondrial origin (within the sperm midpiece; see Fig. I). The sperm mitochondrial DNA is a small, circular DNA that is not bound to proteins. ${ }^{16}$ Mitochondrial DNA exhibits a high rate of mutation. ${ }^{17}$ Sperm motility is related to the mitochondrial volume within the sperm midpiece, and mutations or deletions in the mitochondrial DNA have been associated with reduced sperm motility. ${ }^{17}$ Although inheritance of mitochondrial DNA is primarily maternal, paternal transmission of mitochondrial DNA mutations have been reported (but no more than $\mathrm{I} \%$ of inheritance). ${ }^{18}$ The examination of mitochondrial DNA may gain some importance in the evaluation of male infertility, particularly in relation to assisted reproductive technologies.

\section{Causes of sperm DNA damage}

The causes of sperm DNA damage, much like those of male infertility, have many factors and may be attributed to intraor extratesticular factors. Sperm DNA damage is clearly associated with male infertility (and abnormal spermatogenesis), but a small percentage of spermatozoa from fertile men also possesses detectable levels of DNA damage. ${ }^{2,3,8}$

An important subset of infertile men (about 5\%-I5\%), but not of fertile men, possess a complete protamine deficiency. ${ }^{15,19}$ Studies on transgenic animal models with targeted protamine deficiency suggest a link between protamine deficiency, sperm DNA damage and poor fertilizing capacity during in vitro fertilization (IVF). ${ }^{7}$ A single case report indicated that a febrile illness can cause a transient increase in the nu- clear histone : protamine ratio and associated abnormalities of sperm chromatin structure. ${ }^{20}$ This association between sperm DNA damage and protamine deficiency suggests that the damage may be due to a defect in spermiogenesis (the period during which sperm protamines are deposited).

Sperm DNA damage has been associated with high levels of reactive oxygen species, high levels of which have been detected in the semen of $25 \%$ of infertile men. ${ }^{21}$ Although low levels of reactive oxygen species are necessary for normal sperm function, high levels are generated by defective spermatozoa and by semen leukocytes, which results in sperm dysfunction. The association between sperm DNA damage and sperm-derived reactive oxygen species suggests that DNA damage may be caused by a defect in spermiogenesis, ${ }^{22}$ whereas the association between sperm DNA damage and leukocyte-derived reactive oxygen species suggests that the DNA damage may be caused by a post-testicular defect. ${ }^{23}$

Sperm DNA damage may be due to apoptosis (programmed cell death), although this theory has been challenged. ${ }^{24,25}$ Apoptosis during normal spermatogenesis results in the destruction of up to $75 \%$ of potential spermatozoa. The selective apoptosis of these early germ cells prevents overproliferation of the cells and selectively aborts abnormal sperm forms. ${ }^{26}$ Sakkas and colleagues have proposed that some of the spermatozoa with DNA damage have initiated and subsequently escaped apoptosis ("abortive apoptosis"). ${ }^{24}$ Advancing age and gonadotoxins (e.g., cancer therapies) have been associated with reduced levels of germ cell apoptosis in the testicle and an increased percentage of ejaculated spermatozoa with DNA damage, which suggests that in these men both spermatogenesis and apoptosis have been disrupted. ${ }^{27,28}$

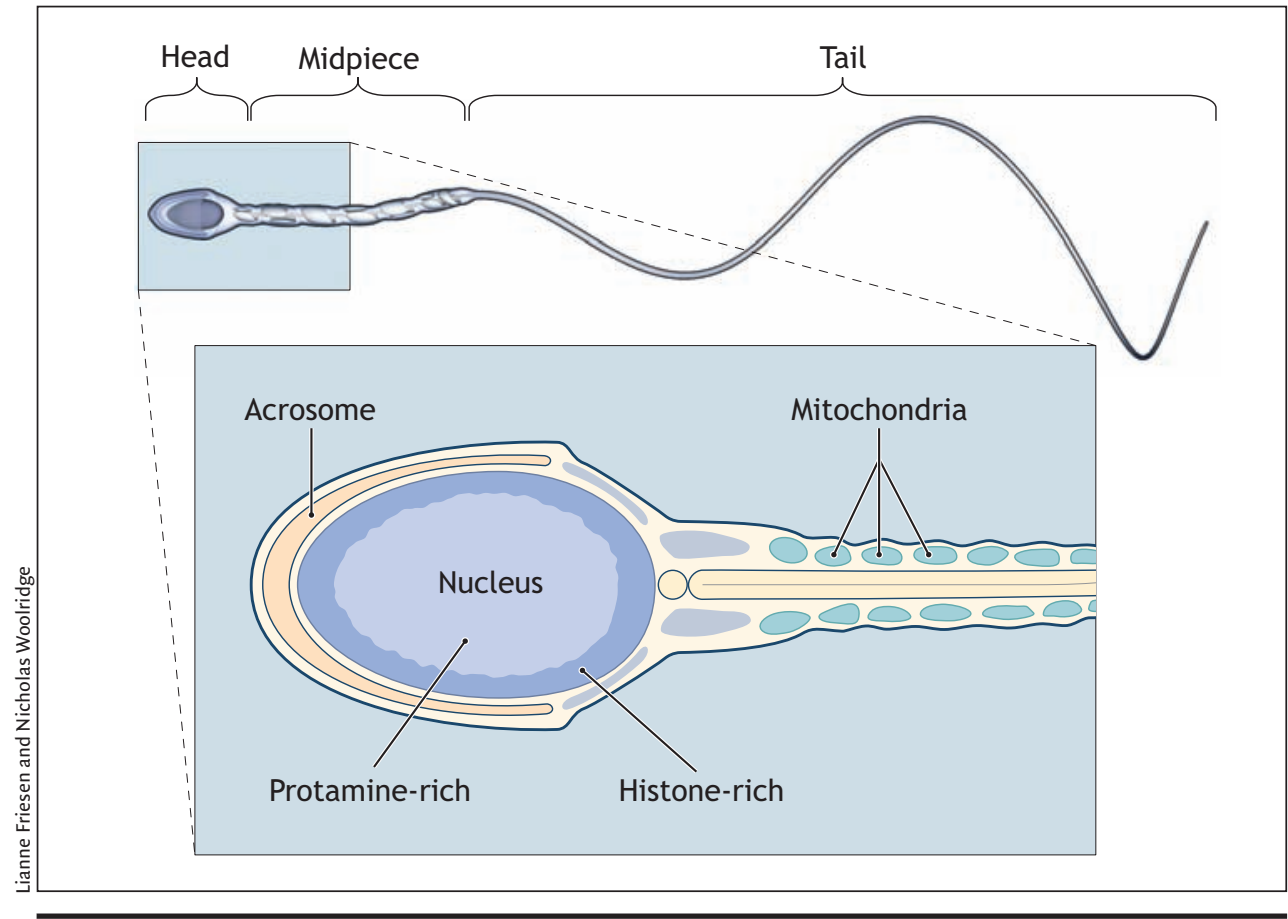

Fig. 1: The human sperm. The sperm head contains the nucleus (DNA and proteins) and the acrosome (a vesicle rich in hydrolytic enzymes involved in egg penetration). Within the sperm nucleus, there is a histone-rich region that is localized peripherally and a protamine-rich region localized centrally. The sperm midpiece represents the proximal part of the sperm tail and is rich in mitochondria. 


\section{Drugs, chemotherapy and radiation therapy}

Young men with cancer (e.g., Hodgkin's lymphoma and testicular cancer) typically have poor semen quality and sperm DNA damage, even before cancer therapy. They then experience cumulative dose-related damage during therapy, which often renders them completely sterile. ${ }^{29,30}$ The rapidly dividing germinal epithelium of the testis is a natural target for cytotoxic medications. Radiation therapy and chemotherapy inflict similar damage and are dependent on both duration and dose of exposure. ${ }^{31,32}$ The recovery of spermatogenesis may occur months to years after therapy, but evidence of sperm DNA damage may often persist beyond that period. ${ }^{33}$ The risk of persistence of germline DNA damage is a cause of concern for many people with cancer. Although there is not much clinical evidence, most clinicians will counsel patients to delay parenthood until I2-24 months after cancer treatment. Patients who are scheduled to undergo definitive cancer therapy (e.g., surgery, chemotherapy, radiation therapy) are strongly encouraged to have their sperm preserved for future use. ${ }^{34}$

\section{Cigarette smoking and environmental toxins}

Studies have shown that cigarette smoking is associated with a decrease in sperm counts and motility and an increase in abnormal sperm forms and sperm DNA damage. ${ }^{35}$ It is suggested that smoking causes increased production of leukocyte-derived reactive oxygen species, which has adverse effects on mature sperm. ${ }^{35}$ Exposure to pesticides (organophosphates) and air pollution has also been associated with increased levels of sperm DNA damage. ${ }^{36,37}$

\section{Genital tract inflammation}

Post-testicular genital tract infection and inflammation (e.g., combined inflammation of the epididymis and testis or of the prostate gland) result in leukocytospermia and have been associated with increased levels of reactive oxygen species and subsequent sperm DNA damage. ${ }^{38}$

\section{Testicular hyperthermia}

A febrile illness has been shown to cause an increase in the histone : protamine ratio and DNA damage in ejaculated spermatozoa. ${ }^{20}$ Direct testicular hyperthermia has also been shown to cause these effects. ${ }^{29,30}$ Certain behaviours have been associated with increased scrotal temperatures (e.g., use of hot baths, saunas, down-filled blankets, laptop computers and prolonged periods of driving). ${ }^{39}$ Although the specific effects on sperm parameters or pregnancy outcomes have not been demonstrated, certain professions have been associated with poorer sperm quality. Farmers, painters and varnishers have been shown to have an increased likelihood of decreased sperm counts, whereas metal workers and welders have been shown to have reduced sperm motility. ${ }^{40}$ Corroborative studies on sperm DNA damage are still lacking.

\section{Varicoceles}

Varicoceles have been associated with sperm DNA damage. ${ }^{41}$ The level of sperm DNA damage is related to the high levels of oxidative stress found in the semen of infertile men with this condition..$^{41}$ Recent studies have demonstrated that varicoceles are associated with the abnormal retention of sperm cytoplasmic droplets (a morphologic feature associated with high levels of reactive oxygen species) and that these retained droplets are correlated with sperm DNA damage in infertile men. ${ }^{42,43}$ Furthermore, sperm DNA integrity has been shown to improve after varicocele repair. ${ }^{44}$

\section{Hormonal factors}

Experimental evidence has demonstrated that hormonal deficiency can cause sperm chromatin defects. Compared with wild-type mice, follice-stimulating-hormone-receptor knockout mice have been found to have lower levels of sperm nuclear protamines and lower testosterone, impaired fertility and higher levels of DNA damage. ${ }^{45}$

\section{Tests of sperm DNA damage}

Many tests of sperm DNA damage are now available. The use of these tests has been driven largely by the growing use of assistive reproductive technologies and an awareness that the integrity of the male genome plays an important role in IVF.

Sperm DNA damage can be measured directly (fragmenta-

Table 1: Commonly used tests of sperm DNA damage

\begin{tabular}{|c|c|c|}
\hline Test & Measures & Characteristics \\
\hline $\begin{array}{l}\text { Sperm chromatin } \\
\text { structure assay }\end{array}$ & $\begin{array}{l}\text { Susceptibility of } \\
\text { sperm DNA to } \\
\text { denaturation }\end{array}$ & $\begin{array}{l}\text { Objective, flow } \\
\text { cytometry-based, } \\
\text { indirect assay, } \\
\text { complex analysis, } \\
\text { used clinically }\end{array}$ \\
\hline $\begin{array}{l}\text { Nuclear protein } \\
\text { composition } \\
\text { (by protein } \\
\text { separation) }\end{array}$ & $\begin{array}{l}\text { Sperm histone } \\
\text { and protamine } \\
\text { levels }\end{array}$ & $\begin{array}{l}\text { Objective, gel } \\
\text { electrophoresis } \\
\text { assay, indirect } \\
\text { assay, labour } \\
\text { intensive }\end{array}$ \\
\hline $\begin{array}{l}\text { Sperm nuclear } \\
\text { maturity test } \\
\text { (by nuclear } \\
\text { staining) }\end{array}$ & $\begin{array}{l}\text { Chromatin } \\
\text { compaction, } \\
\text { protamine } \\
\text { content }\end{array}$ & $\begin{array}{l}\text { Simple, semi- } \\
\text { quantitative, } \\
\text { slide-based, } \\
\text { indirect assay }\end{array}$ \\
\hline $\begin{array}{l}\text { Comet assay } \\
\text { (by single-cell gel } \\
\text { electrophoresis) }\end{array}$ & $\begin{array}{l}\text { Double-stranded } \\
\text { DNA breaks } \\
\text { (neutral assay) }\end{array}$ & $\begin{array}{l}\text { Objective, } \\
\text { quantitative, direct } \\
\text { assay, complex } \\
\text { image analysis }\end{array}$ \\
\hline TUNEL assay & $\begin{array}{l}\text { Double-stranded } \\
\text { DNA breaks }\end{array}$ & $\begin{array}{l}\text { Semi-quantitative, } \\
\text { direct assay, } \\
\text { quantitative if flow } \\
\text { cytometry-based }\end{array}$ \\
\hline DNA oxidation & $\begin{array}{l}\text { 8-hydroxy-2- } \\
\text { deoxyguanosine }\end{array}$ & $\begin{array}{l}\text { Quantitative, } \\
\text { direct assay, } \\
\text { labour intensive }\end{array}$ \\
\hline
\end{tabular}

Note: TUNEL = terminal deoxynucleotidyl transferase-mediated dUTP-nick end-labelling. 
tion, oxidation) or indirectly (sperm chromatin compaction) (Table I). Direct assessment of DNA damage can be obtained by means of single-cell gel electrophoresis assay or "Comet" assay (electrophoresis causes DNA fragments to migrate away from the central DNA core, revealing a "comet"), terminal deoxynucleotidyl transferase-mediated dUTP-nick endlabelling or "TUNEL" assay (the ends of fragmented DNA are tagged) and liquid chromatography to measure DNA oxidation levels. ${ }^{8,46}$ DNA damage can also be assessed indirectly by means of sperm chromatin integrity assays and by evaluation of nuclear protein levels..$^{2-4,47,48}$ Sperm chromatin integrity assays include slide-based sperm nuclear protein stains (e.g., aniline or toludine blue [detects histones], $\mathrm{CMA}_{3}$ [detects underprotamination]) and DNA stains (e.g., acridine orange [detects denatured or single-stranded DNA]). ${ }^{47,48}$ The sperm chromatin structure assay uses flow cytometry to estimate the percentage of spermatozoa with DNA denaturation (spermatozoa are stained with acridine orange). ${ }^{2-4}$ Nuclear protein levels are assessed by means of protein extraction, gel separation and immunoblotting with specific antibodies. ${ }^{49}$

\section{Effect of sperm DNA damage on reproductive outcomes}

The integrity of the sperm DNA may be tested to predict pregnancy outcomes in couples who do not know their fertility potential (i.e., first pregnancy). Couples in whom the man has a high percentage of spermatozoa with DNA damage have very low potential for natural fertility ${ }^{2,3}$ and will have to wait a long time before conceiving. ${ }^{50}$ Couples whose pregnancy resulted in miscarriage demonstrate a trend toward poorer sperm DNA integrity compared with highly fertile couples. ${ }^{2}$

With the advent of IVF and intracytoplasmic sperm injection (ICSI); (the direct injection of sperm DNA, damaged or otherwise, into an oocyte), the concern over using damaged DNA has become apparent. In natural conception, a DNAdamaged sperm would likely be unsuccessful in fertilizing an egg. Human spermatozoa that bind to oviduct (fallopian tube) cells have better DNA integrity than spermatozoa that do not bind to these cells, which suggests that nature can select spermatozoa with enhanced DNA integrity during natural fertilization. ${ }^{51}$ However, assistive reproductive technologies bypass this selection process, which may result in the inadvertent use of DNA-damaged spermatozoa.

Numerous studies have examined the possible influence of sperm DNA integrity on reproductive outcomes after both standard IVF and IVF/ICSI (Table 2). There is no consistent relation between sperm DNA damage and fertilization rates during IVF or IVF/ICSI. ${ }^{52-65}$ Neither fertilization nor early embryo development is dependent on sperm DNA integrity, since the embryonic genome is not expressed until after the second cleavage division (i.e., at the 4 -cell embryo). ${ }^{66}$ There is also no consistent relation between sperm DNA damage and embryo quality after ICSI (roughly half of the studies have shown an adverse effect of DNA damage on embryo quality). However, high levels of sperm DNA damage are inversely related to pregnancy rates in most, but not all, studies. ${ }^{52-65}$ These clinical observations are not entirely consistent with animal studies, which indicate that DNA damage is associated with both poor

Table 2: Influence of sperm DNA damage on fertilization rates, embryo quality and pregnancy rates during IVF and IVF/ICSI

Influence of sperm DNA damage*

\begin{tabular}{|c|c|c|c|c|c|c|}
\hline Study & $\begin{array}{l}\text { IVF, no. of } \\
\text { subjects }\end{array}$ & $\begin{array}{l}\text { ICSI, no. of } \\
\text { subjects }\end{array}$ & $\begin{array}{l}\text { On fertilization } \\
\text { rates }\end{array}$ & $\begin{array}{l}\text { On embryo } \\
\text { quality }\end{array}$ & $\begin{array}{l}\text { On pregnancy } \\
\text { rates }\end{array}$ & Assay used \\
\hline Lopes, $1998^{52}$ & 0 & 150 & $\downarrow$ & 0 & NA & TUNEL \\
\hline Host, $2000^{53}$ & 50 & 61 & $\downarrow$ IVF & NA & NA & TUNEL \\
\hline Tomlinson, $2001^{54}$ & 140 & 0 & 0 & 0 & $\downarrow$ & TUNEL \\
\hline Tomsu, $2002^{55}$ & 40 & 0 & 0 & $\downarrow$ & $\downarrow$ & Comet \\
\hline Morris, $2002^{56}$ & 20 & 40 & 0 & $\downarrow$ & NA & Comet \\
\hline Benchaib, $2003^{57}$ & 50 & 54 & $\downarrow$ & 0 & $\downarrow$ \ICSI & TUNEL \\
\hline Larson-C, $2003^{58}$ & 55 & 34 & 0 & 0 & $\downarrow$ & SCSA \\
\hline Henkel $2004^{62}$ & 249 & 0 & 0 & NA & $\downarrow$ & TUNEL \\
\hline Seli, $2004^{60}$ & 49 & 0 & NA & $\downarrow$ & 0 & TUNEL \\
\hline Virro, $2004^{61}$ & 249 & - & 0 & $\downarrow$ & $\downarrow$ & SCSA \\
\hline Bungum, $2004^{59}$ & 109 & 66 & NA & NA & 0 & SCSA \\
\hline Payne, $2005^{63}$ & 46 & 54 & $\downarrow$ & NA & $\uparrow \uparrow$ & SCSA \\
\hline Huang, $2005^{64}$ & 217 & 86 & $\downarrow$ & 0 & 0 & TUNEL \\
\hline Zini, $2005 b^{65}$ & 0 & 60 & 0 & $\downarrow$ & 0 & SCSA \\
\hline
\end{tabular}

Note: IVF = in vitro fertilization, ICSI = intracytoplasmic sperm injection, NA = not available, TUNEL = terminal deoxynucleotidyl transferasemediated dUTP-nick end-labelling, Comet = single-cell gel electrophoresis assay, SCSA = sperm chromatin structure assay.

* $\downarrow$ = sperm DNA damage is associated with poor reproductive outcome, $0=$ sperm DNA damage has no effect on reproductive outcome.

$\dagger$ The atypical results may be due to the high proportion of couples with female factor infertility. 
embryo development and poor pregnancy outcomes. This is probably because the stringent process of sperm and embryo selection during ICSI will mitigate the potential adverse effects of sperm DNA damage on reproductive outcomes. ${ }^{6}$

It is now known that IVF/ICSI is associated with an increased (although relatively low) risk of birth defects and genetic and epigenetic abnormalities in the child. To date, it is unclear whether it is the ICSI procedure or the underlying infertility that is responsible for these defects. ${ }^{67-70}$ The risk of birth defects (major and minor) was found to be significantly higher (odds ratio $\sim$ I.5) among children conceived through IVF/ICSI than among naturally conceived children. ${ }^{67,71}$ The prevalence of chromosomal abnormalities (de novo abnormalities) was found to be significantly higher (I.6\%/0.5\%) among children conceived through ICSI than among naturally conceived children..$^{70}$ Epigenetic abnormalities, such as errors in DNA methylation, have been linked to certain rare genetic diseases (Beckwith/Wiedemann and Angelman's syndromes) and, while still rare, are found in slightly higher numbers among children conceived through IVF/ICSI than among naturally conceived children. ${ }^{72}$

To date, the short- and long-term ramifications of successful fertilization and development with DNA-damaged spermatozoa are unknown. Clearly, the understanding that sperm DNA damage is common in infertile men, together with the concerning preliminary reports on genetic and epigenetic abnormalities in children conceived through ICSI, urge us to explore the subject of sperm DNA damage further. DNA that possesses measurable damage (specifically, DNA oxidation) may cause misreading errors to occur during DNA replication, and this might cause de novo mutations. ${ }^{73}$ Although the concept has not been tested in the context of mammalian reproduction, we cannot dismiss the possibility that successful fertilization with DNA-damaged sperm may cause de novo mutations in the offspring (despite the ability of the oocyte and embryo to repair this DNA damage) ${ }^{6}$ For example, studies have found that children of fathers who smoked cigarettes preconceptually have a higher risk of childhood cancers than do children of nonsmoking fathers. ${ }^{74}$ These studies suggest that there may be a link between sperm DNA damage and the subsequent development of childhood diseases.

\section{Clinical value of tests of sperm DNA damage}

Based on the current evidence, the clinical indications for tests of sperm DNA damage as follows:

- Counselling people who are planning their first pregnancy: these tests (especially the sperm chromatin structure assay) are good predictors of negative pregnancy outcomes. ${ }^{2,3}$ If the male partner has high levels of sperm DNA damage, the couples should consider advanced forms of assisted reproduction (IVF or ICSI) to achieve a pregnancy.

- Counselling people planning to undergo intrauterine insemination: these tests (especially the sperm chromatin structure assay) are good predictors of negative pregnancy outcome. ${ }^{59}$ If the male partner has high levels of sperm DNA damage, the couple should consider IVF or ICSI instead.
- Counselling people planning to undergo IVF or ICSI: these tests are only fair predictors of negative or positive pregnancy outcomes. ${ }^{58,59,61,62}$

- Conducting reproductive toxicology studies and longitudinal studies: these tests (especially the sperm chromatin structure assay) are objective, highly reproducible (much more so than conventional semen parameters) and can be performed on frozen samples.

- Monitoring the potential risk to offspring: these tests can be used, but the optimal test for this purpose is not known. Further study using longer follow-up periods is necessary to ascertain the real risk of birth defects and the potential future development of genetically linked diseases.

\section{Summary}

Successful human reproduction depends in part on the inherent integrity of the sperm DNA. There appears to be a threshold of sperm DNA damage beyond which embryo development and subsequent pregnancy outcome are impaired. Clinical evidence now shows that sperm DNA damage is detrimental to reproductive outcomes and that the spermatozoa of infertile men possess substantially more DNA damage than do the spermatozoa of fertile men. However, our understanding of the causes of sperm DNA damage and the full impact of this sperm defect on reproductive outcomes in humans remains rudimentary. Additional studies are needed to fully define the clinical value of testing of sperm DNA damage.

This article has been peer reviewed.

From the Division of Urology, Department of Surgery, McGill University, Montréal, Que.

Competing interests: None declared.

Contributors: Both authors drafted the article, revised it critically for important intellectual content and gave final approval of the version to be published.

\section{REFERENCES}

I. Evenson DP, Jost LK, Marshall D, et al. Utility of the sperm chromatin assay as a diagnostic and prognostic tool in the human fertility clinic. Hum Reprod I999; I4: I039-49.

2. Spano M, Bonde JP, Hjollund HI, et al. Sperm chromatin damage impairs human fertility. Fertil Steril 2000;73:43-50.

3. Zini A, Bielecki R, Phang D, et al. Correlations between two markers of sperm DNA integrity, DNA denaturation and DNA fragmentation, in fertile and infertile men. Fertil Steril 2001;75:674-7.

4. Guzick DS, Overstreet JW, Factor-Litvak P, et al. Sperm morphology, motility, and concentration in infertile and fertile men. NEngl JMed 200I;345:1388-93.

5. Primakoff P, Myles DG. Penetration: adhesion, and fusion in mammalian spermegg interaction. Science 2002;296:2183-5.

6. Ahmadi A, Ng SC. Fertilizing ability of DNA-damaged spermatozoa. J Exp Zool I999;284:696-704.

7. Cho C, Jung-Ha H, Willis WD, et al. Protamine 2 deficiency leads to sperm DNA damage and embryo death in mice. Biol Reprod 2003;69:21I-7.

8. Kodama H, Yamaguchi R, Fukuda J, et al. Increased oxidative deoxyribonucleic acid damage in the spermatozoa of infertile male patients. Fertil Steril 1997;68: 519-24.

9. Ward WS, Coffey DS. DNA packaging and organization in mammalian spermatozoa: comparison with somatic cells. Biol Reprod I99I;44:569-74.

Io. Brewer LR, Corzett M, Balhorn R. Protamine induced condensation and decondensation of the same DNA molecule. Science 1999;286:120-3.

II. Steger K, Pauls K, Klonisch T, et al. Expression of protamine-I and -2 mRNA during human spermiogenesis. Mol Hum Reprod 2000;6:219-25.

I2. Kosower NS, Katayose H, Yanagimachi R. Thiol-disulfide status and acridine orange fluorescence of mammalian sperm nuclei. J Androl I992;13:342-8. 
I3. Gatewood JM, Cook GR, Balhorn R, et al. Sequence-specific packaging of DNA in human sperm chromatin. Science $1987 ; 236: 962-4$.

I4. Gineitis AA, Zalenskaya IA, Yau PM, et al. Human sperm telomere-binding complex involves histone $\mathrm{H}_{2} \mathrm{~B}$ and secures telomere membrane attachment. J Cell Biol 2000;I5I:I59I-8.

I5. Oliva R. Protamines and male infertility. Hum Reprod Update 2006;12:4I7-35.

I6. Anderson S, Bankier AT, Barrell BG, et al. Sequence and organization of the human mitochondrial genome. Nature i981;290:457-65.

I7. Kao SH, Chao HT, Wei YH. Multiple deletions of mitochondrial DNA are associated with the decline of motility and fertility of human spermatozoa. Mol Hum Reprod I998;4:657-66.

I8. Schwartz M, Vissing J. Paternal inheritance of mitochondrial DNA. N Engl J Med 2002;347:576-80.

19. Carrell DT, Liu L. Altered protamine 2 expression is uncommon in donors of known fertility, but common among men with poor fertilizing capacity, and may reflect other abnormalities of spermiogenesis. J Androl 2001;22:604-Io.

20. Evenson DP, Jost LK, Corzett M, et al. Characteristics of human sperm chromatin structure following an episode of influenza and high fever: a case study. J Androl 2000;2I:739-46.

2I. Irvine DS, Twigg JP, Gordon EL, et al. DNA integrity in human spermatozoa: relationships with semen quality. J Androl 2000;2I:33-44.

22. Gomez E, Buckingham DW, Brindle J, et al. Development of an image analysis system to monitor the retention of residual cytoplasm by human spermatozoa: correlation with biochemical markers of the cytoplasmic space, oxidative stress, and sperm function. J Androl $1996 ; 17: 276-87$.

23. Ochsendorf FR. Infections in the male genital tract and reactive oxygen species. Hum Reprod Update 1999;5:399-420.

24. Sakkas D, Seli E, Bizzaro D, et al. Abnormal spermatozoa in the ejaculate: abortive apoptosis and faulty nuclear remodeling during spermatogenesis. Reprod Biomed Online 2003;7:428-32.

25. Muratori M, Piomboni P, Baldi E, et al. Functional and ultrastructural features of DNA-fragmented human sperm. J Androl 2000;21:903-12.

26. Sinha Hikim AP, Swerdloff RS. Hormonal and genetic control of germ cell apoptosis in the testis. Rev Reprod 1999;4:38-47.

27. Singh NP, Muller CH, Berger RE. Effects of age on DNA double-strand breaks and apoptosis in human sperm. Fertil Steril 2003;80:1420-30.

28. Brinkworth $\mathrm{MH}$, Nieschlag E. Association of cyclophosphamide-induced malemediated, foetal abnormalities with reduced paternal germ-cell apoptosis. Mutat Res 2000;447:149-54.

29. Sailer BL, Sarkar LJ, Bjordahl JA, et al. Effects of heat stress on mouse testicular cells and sperm chromatin structure. J Androl I997;I8:294-30I.

30. Banks S, King SA, Irvine DS, et al. Impact of a mild scrotal heat stress on DNA integrity in murine spermatozoa. Reproduction 2005;I29:505-I4.

3I. Morris ID. Sperm DNA damage and cancer treatment. Int J Androl 2002a;25:255-6I.

32. Sailer BL, Jost LK, Erickson KR, et al. Effects of X-irradiation on mouse testicular cells and sperm chromatin structure. Environ Mol Mutagen 1995;25:23-30.

33. Fossa SD, De Angelis P, Kraggerud SM, et al. Prediction of post-treatment spermatogenesis in patients with testicular cancer by flow cytometric sperm chromatin structure assay. Cytometry 1997;30:192-6.

34. Lee SJ, Schover LR, Partridge AH, et al. American Society of Clinical Oncology Recommendations on Fertility Preservation in Cancer Patients. J Clin Oncol 2006;24: 2917-3I.

35. Potts RJ, Newbury CJ, Smith G, et al. Sperm chromatin damage associated with male smoking. Mutat Res 1999;423:103-II.

36. Rubes J, Selevan SG, Evenson DP, et al. Episodic air pollution is associated with increased DNA fragmentation in human sperm without other changes in semen quality. Hum Reprod 2005;20:2776-83.

37. Sanchez-Pena LC, Reyes BE, Lopez-Carrillo L, et al. Organophosphorous pesticide exposure alters sperm chromatin structure in Mexican agricultural workers. Toxicol Appl Pharmacol 2004;196:I08-I3.

38. Erenpreiss J, Hlevicka S, Zalkalns J, et al. Effect of leukocytospermia on sperm DNA integrity: a negative effect in abnormal semen samples. J Androl 2002;23:717-23.

39. Jung A, Schill WB, Schuppe HC. Genital heat stress in men of barren couples: a prospective evaluation by means of a questionnaire. Andrologia 2002;34:349-55.

40. Kenkel S, RolfC, Nieschlag E. Occupational risks for male infertility: an analysis of patients attending a tertiary referral centre. Int J Androl 2001;24:318-26.

4I. Saleh RA, Agarwal A, Sharma RK, et al. Evaluation of nuclear DNA damage in spermatozoa from infertile men with varicocele. Fertil Steril 2003;80:I43I-6.

42. Fischer MA, Willis J, Zini A. Human sperm DNA integrity: correlation with sperm cytoplasmic droplets. Urology 2003;6r:207-II.

43. Zini A, Defreitas G, Freeman M, et al. Varicocele is associated with the abnormal retention of cytoplasm by human spermatozoa. Fertil Steril 2000;74:46I-4.

44. Zini A, Blumenfeld A, Libman J, et al. Beneficial effect of microsurgical varicocelectomy on human sperm DNA integrity. Hum Reprod 2005a;20:I0I8-2I.

45. Xing W, Krishnamurthy H, Sairam MR. Role of follitropin receptor signaling in nuclear protein transitions and chromatin condensation during spermatogenesis. Biochem Biophys Res Commun 2003;312:697-701.

46. Aravindan GR, Bjordahl J, Jost LK, et al. Susceptibility of human sperm to in situ DNA denaturation is strongly correlated with DNA strand breaks identified by single-cell electrophoresis. Exp Cell Res 1997;236:23I-7.
47. Erenpreiss J, Bars J, Lipatnikova V, et al. Comparative study of cytochemical tests for sperm chromatin integrity. J Androl 2001;22:45-53.

48. Bianchi PG, Manicardi GC, Bizzaro D, et al. Effect of deoxyribonucleic acid protamination on fluorochrome staining and in situ nick-translation of murine and human mature spermatozoa. Biol Reprod 1993;49:1083-8.

49. Zhang X, San Gabriel M, Zini A. Sperm nuclear protamine to histone ratio in fertile and infertile men: evidence of heterogeneous sub-populations of spermatozoa in the ejaculate. J Androl 2006;27:4I4-20.

50. Loft S, Kold-Jensen T, Hjollund NH, et al. Oxidative DNA damage in human sperm influences time to pregnancy. Hum Reprod 2003;18:1265-72.

5I. Ellington J, Evenson DP, Wright RW Jr, et al. Higher quality human sperm in sample selectively attach to oviduct (fallopian tube) epithelial cells in vitro. Fertil Steril 1999;7I:924-9.

52. Lopes S, Sun JG, Jurisicova A, et al. Sperm deoxyribonucleic acid fragmentation is increased in poor-quality semen samples and correlates with failed fertilization in intracytoplasmic sperm injection. Fertil Steril 1998;69:528-32.

53. Host E, Lindenberg S, Smidt-Jensen S. The role of DNA strand breaks in human spermatozoa used for IVF and ICSI. Acta Obstet Gynecol Scand 2000;79:559-63.

54. Tomlinson MJ, Moffatt O, Manicardi GC, et al. Interrelationships between seminal parameters and sperm nuclear DNA damage before and after density gradient centrifugation: implications for assisted conception. Hum Reprod 2001;16:2160-5

55. Tomsu M, Sharma V, Miller D. Embryo quality and IVF treatment outcomes may correlate with different sperm comet assay parameters. Hum Reprod 2002;17: I856-62.

56. Morris ID, Ilott S, Dixon L, et al. The spectrum of DNA damage in human sperm assessed by single cell gel electrophoresis (Comet assay) and its relationship to fertilization and embryo development. Hum Reprod 2002b;17:990-8.

57. Benchaib M, Braun V, Lornage J, et al. Sperm DNA fragmentation decreases the pregnancy rate in an assisted reproductive technique. Hum Reprod 2003;18:1023-8.

58. Larson-Cook KL, Brannian JD, Hansen KA, et al. Relationship between the outcomes of assisted reproductive techniques and sperm DNA fragmentation as measured by the sperm chromatin structure assay. Fertil Steril 2003;80:895-902.

59. Bungum M, Humaidan $P$, Spano M, et al. The predictive value of sperm chromatin structure assay (SCSA) parameters for the outcome of intrauterine insemination, IVF and ICSI. Hum Reprod 2004;I9:I40I-8.

6o. Seli E, Gardner DK, Schoolcraft WB, et al. Extent of nuclear DNA damage in ejaculated spermatozoa impacts on blastocyst development after in vitro fertilization. Fertil Steril 2004;82:378-83

6I. Virro MR, Larson-Cook KL, Evenson DP. Sperm chromatin structure assay (SCSA) parameters are related to fertilization, blastocyst development, and ongoing pregnancy in in vitro fertilization and intracytoplasmic sperm injection cycles. Fertil Steril 2004;8I:I289-95.

62. Henkel R, Hajimohammad M, Stalf T, et al. Influence of deoxyribonucleic acid damage on fertilization and pregnancy. Fertil Steril 2004;81:965-72.

63. Payne JF, Raburn DJ, Couchman GM, et al. Redefining the relationship between sperm deoxyribonucleic acid fragmentation as measured by the sperm chromatin structure assay and outcomes of assisted reproductive techniques. Fertil Steril $2005 ; 84: 356-64$

64. Huang CC, Lin DP, Tsao HM, et al. Sperm DNA fragmentation negatively correlates with velocity and fertilization rates but might not affect pregnancy rates. Fertil Steril 2005;84:I30-40.

65. Zini A, Meriano J, Kader K, et al. Potential adverse effect of sperm DNA damage on embryo quality after ICSI. Hum Reprod 2005;20:3476-80.

66. Braude P, Bolton V, Moore S. Human gene expression first occurs between the fourand eight-cell stages of preimplantation development. Nature I988;332:459-6I.

67. Hansen M, Kurinczuk J, Bower C, et al. The risk of major birth defects after intracytoplasmic sperm injection and in vitro fertilization. N Engl JMed 2002;346:725-30.

68. Ludwig M, Katalinic A, Gross S, et al. Increased prevalence of imprinting defects in patients with Angelman syndrome born to subfertile couples. J Med Genet 2005;42:289-9I.

69. Cox GF, Burger J, Lip V, et al. Intracytoplasmic sperm injection may increase the risk of imprinting defects. Am J Hum Genet 2002;71:I62-4

70. Bonduelle M, Aytoz A, Van Assche E, et al. Incidence of chromosomal aberrations in children born after assisted reproduction through intracytoplasmic sperm injection. Hum Reprod I998;13:78I-2.

7I. Hansen M, Bower C, Milne E, et al. Assisted reproductive technologies and the risk of birth defects-a systemic review. Hum Reprod 2005;20:328-38.

72. Maher ER, Brueton LA, Bowdin SC, et al. Beckwith-Wiedemann syndrome and assisted reproduction technology (ART). J Med Genet 2003;40:62-4.

73. Kuchino Y, Mori F, Kasai H, et al. Misreading of DNA templates containing 8hydroxydeoxyguanosine at the modified base and at adjacent residues. Nature I987;327:77-9.

74. Ji BT, Shu XO, Linet MS, et al. Paternal cigarette smoking and the risk of childhood cancer among offspring of nonsmoking mothers. J Natl Cancer Inst 1997;89:238-44.

Correspondence to: Dr. Armand Zini, Rm. 2304, St. Mary's

Hospital, 3830 Lacombe Ave., Montréal QC $H_{3} T_{1}$ IM5; $_{5}$

fax 514 734-2718; armand.zini@ssss.gouv.qc.ca 